Letter

\title{
Two phase modulation for inverter-driven hybrid-excitation-type synchronous machines \\ ハイブリッド励磁形同期機駆動用インバータの駆動方式に関する研究
}

\author{
Hirotaka SUZUKI, Takehisa HIRAYAMA, Muhamed Fitri Bin Hanafi and Hideki OHGUCHI \\ Department of Electrical and Electronic Engineering, Faculty of Engineering, Tokai University, 4-1-1 \\ Kitakaname, Hiratsuka, Kanagawa, 259-1292 Japan \\ TEL:x81-463-58-1211(EX.6243) FAX:x81-463-50-2426 e-mail: ohguchi@tsc.u-tokai.ac.jp \\ (Received 27 December, $2019 \quad$ Accepted 12 February, 2020)
}

\begin{abstract}
A novel inverter without the chopper for the field circuit was proposed for hybrid-excitation-type synchronous machines. In this inverter, a switch is connected between the neutral point of the armature windings of the machine and the field circuit. The field flux in the machine is increased when the switch is on, and is unchanged when off. By using a circuit simulator, we have clarified that two phase modulation can be used to the inverter when the switch is off.
\end{abstract}

Keywords : Hybrid-excitation-type synchronous machine, Permanent magnet, Inverter, Two phase modulation

\section{INTRODUCTION}

現在、様々な機械に永久磁石モータ（PM モータ）が 採用されている。永久磁石モータが採用される理由とし て、回転子に内蔵された永久磁石が磁束を発生させるこ とで誘導機のように回転子に二次電流が流れないため損 失が低減し、高効率化と小型・軽量化を実現可能なため であることが挙げられる。PM モータの適用例として、 自動車が挙げられる。自動車用主機モー夕は、低速域で は大トルクかつ最高回転速度が高いという特徴がある。 また、高トルクを発生させるためには界磁磁束が高い方 が良く、高速回転させるためには界磁磁束が低い方が適 する。

近年、自動車用 PM モータの高効率化を実現するべく モータ内の磁束を調整できる可変磁束モータの研究が進 められている。可変磁束モータの 1 つである 1 ハイブリ ッド励磁形同期機は、永久磁石と直流界磁巻線により界 磁磁束を得ることができ、また永久磁石からの界磁を増 減可能である。すなわち、可変磁束モータは、モータの 運転中に電機子鎖交磁束を調整することが可能であり低 速域での電流低減が可能となる利点がある。その反面、 従来のハイブリッド励磁形同期機を駆動するためのパワ

SAS Award was given to this paper presented as Poster Presentation at the 2019 SAS Symposium.
一エレクトロニクス装置はインバータとチョッパ二つ必 要なため装置が大型化する可能性がある。装置の簡素化 を目的として、本研究者らはハイブリッド励磁形同期機 駆動用装置をインバータのみとした回路を²提案した。

インバータの変調方式の 1 つとして ${ }^{3}$ 二相変調がある。 これは、元の正弦波の電圧指令值に零相成分を重畳する 方式である。二相変調を行う上で、通常零相成分の電流 は流れない。一方、界磁回路を制御するには零相成分を 流す必要があり、Fig. 1 のモー夕電機子巻線の中性点 $\mathrm{O}$ と界磁回路を界磁制御スイッチ $\mathrm{S}_{0}$ を介して接続すると、 二相変調の指令值に含有される零相電圧による電流も流 れると考えられる。この場合、インバータは動作困難と なると考えられるものの、零相電流が流れる回路におい て二相変調を適用した場合に、回路にどのような電流が 流れるのか明らかとなっていない。そこで、本研究では 提案回路において、界磁回路オフにおける二相変調の適 用可否と、界磁回路オンにおける二相変調適用時のイン バータ動作の明確化を目的とし、シミュレーションによ り検証したので報告する。

\section{METHODS}

Fig. 1 に提案する簡素化したハイブリッド励磁形同期 機駆動装置の回路図を示す。本回路は、(a)インバータ、 (b)モー夕等価回路、(c)界磁制御スイッチ $\mathrm{S}_{0} 、(d)$ 界磁回路 
から構成される。(a)のインバータは、直流を交流に変換 する回路であり、6 つの IGBT でスイッチングを行い PWM 制御を行う。(b)のモータ等価回路は、誘起電圧、 巻線抵抗、漏れインダクタンスで構成される。(c)の界磁 制御スイッチ $\mathrm{S}_{0}$ は、界磁回路の動作のオン・オフを切り 替えるためのスイッチである。(d)の界磁回路は、平滑コ ンデンサと抵抗で構成され、抵抗は界磁巻線の巻線抵抗 を表す。(d)の界磁回路の一方は界磁制御スイッチ $\mathrm{S}_{0}$ を介 してモータ電機子巻線の中性点 $\mathrm{O}$ 一接続され、他方はイ ンバータの Nラインへ接続される。界磁制御スイッチ $\mathrm{S}_{0}$ をオンとすると界磁磁束が増加し、オフとすると界磁は 永久磁石のみとなる。また、Fig. 2 に示すようにハイブリ ッド励磁形同期機は、(i)永久磁石、(ii)固定子鉄心、(iii) ヨ ーク、(iv)回転子鉄心、(v)界磁巻線、(vi)シャフトから構 成される。永久磁石と直流界磁巻線から界磁磁束を得る ことができ、また永久磁石からの界磁を増減可能となる。

インバータの変調方式として二相変調を適用する。

Fig. 3 に二相変調の波形を示す。 $v_{u}{ }^{*}$ は元の正弦波の相電 圧の指令值、 $v_{u}{ }^{* *}$ は零相を重畳した相電圧指令值、 $v_{u v}$ は 線間電圧である。Fig. 3 より、 $v_{u}{ }^{* *}$ は正弦波ではないもの の、 $v_{u v}$ は正弦波となる。すなわち、インバータ出力線間 電圧は正弦波となる。また、二相変調は三相変調に対し てスイッチング回数が $2 / 3$ 回に低減するためスイッチン グ損失が低減するとともに電圧利用率が向上するという 利点がある。

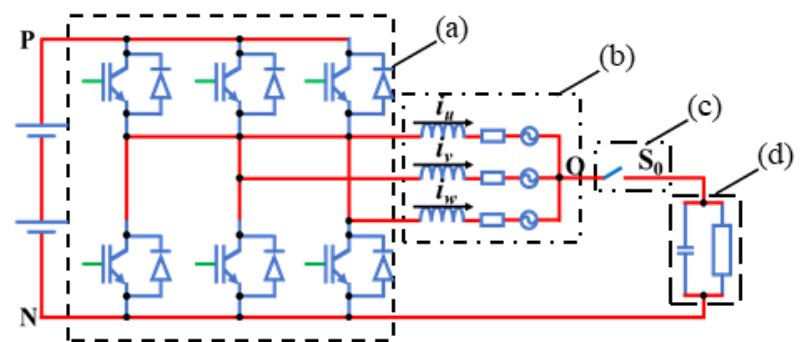

Fig. 1. Circuit configuration for hybrid-excitation-type synchronous machines.

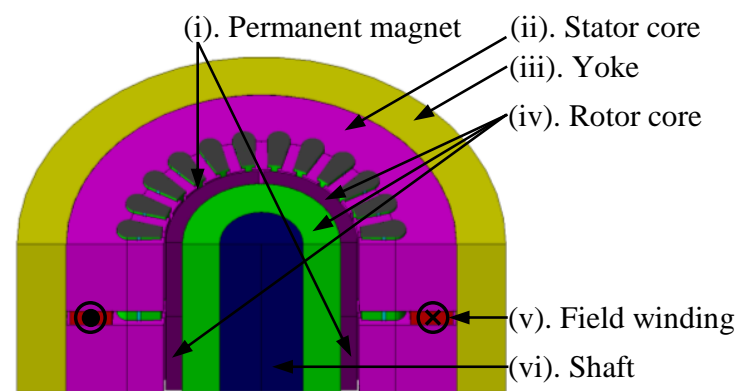

Fig. 2. Structural drawing for hybrid-excitation-type synchronous machine.
今回界磁制御スイッチ $\mathrm{S}_{0}$ をオンまたはオフとした場 合において、Fig. 1 に示すインバータへ二相変調を適用 し、回路動作をシミュレーションにより明確化する。本 研究では回路シミュレータPSIM を用いた。

Table 1 に解析条件を示す。

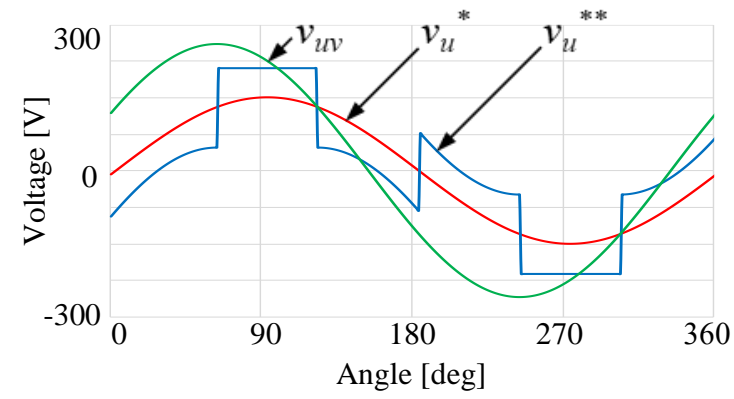

Fig. 3. Voltage waveforms of two-phase modulation.

Table 1. Simulation conditions.

\begin{tabular}{|c|c|c|c|}
\hline $\begin{array}{c}\text { Modulation } \\
\text { method }\end{array}$ & $\begin{array}{c}\text { Target value of } \\
\text { current amplitude }\end{array}$ & $\begin{array}{c}\text { Inverter output } \\
\text { frequency }\end{array}$ & $\mathrm{S}_{0}$ \\
\hline $\begin{array}{c}\text { Two-phase } \\
\text { modulation }\end{array}$ & $4.3 \mathrm{~A}$ & $50 \mathrm{~Hz}$ & off \\
\cline { 3 - 4 } & on \\
\hline
\end{tabular}

\section{RESULTS}

Fig. 4 に $\mathrm{S}_{0}=$ オフとしたときの、Fig. 5 に $\mathrm{S}_{0}=$ オンと したときのインバータ出力電流波形をそれぞれ示す。

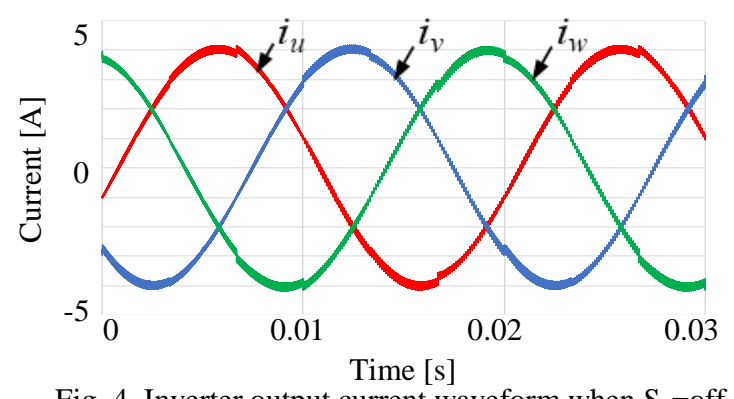

Fig. 4. Inverter output current waveform when $S_{0}=$ off.

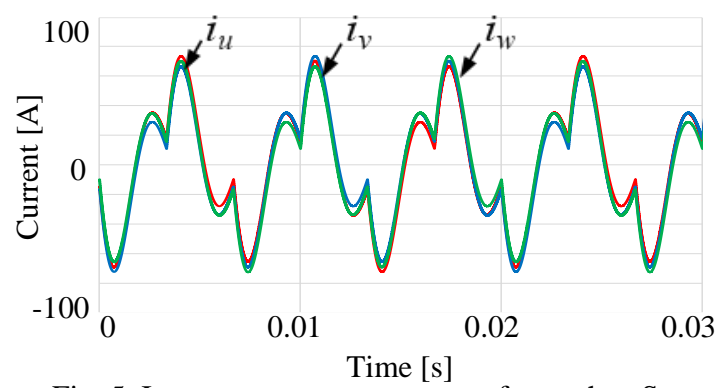

Fig. 5. Inverter output current waveform when $S_{0}=$ on. 
Fig. 4 より界磁制御スイッチ $\mathrm{S}_{0}$ オフ時はインバータ出 力電流が交流電流となり目標值と同じ波高值約 $4.3 \mathrm{~A}$ 、周 波数 $50 \mathrm{~Hz}$ の電流が出力されていることが分かる。また、 Fig. 5 より界磁制御スイッチ $\mathrm{S}_{0}$ オン時はインバータ出力 電流の波高值が目標值の 15 倍を超え、かつ電流波形が 歪夕、三相同一かつ三倍の周波数の電流が出力されてい ることが分かる。通常の二相変調では流れない零相電流 が流れたためインバータ出力電流が増加し、電流波形に 歪みが生じたと考えられる。また、二相変調波形生成の ための零相電圧は交流であり、この交流成分に対して界 磁回路に備えるコンデンサは低インピーダンスとなる。 そのため、零相電圧に起因する零相電流がコンデンサを 流れることで、インバータ出力電流が増加し、電流波形 が歪んだと考えられる。

\section{IV.CONCLUSION}

本研究では、ハイブリッド励磁形同期機駆動用の装置 をインバータのみとした回路において、二相変調を適用 した時の回路動作の明確化を目的とし、回路シミュレー タPSIM を用いて解析を行った。結果、界磁制御スイッチ
$\mathrm{S}_{0}$ をオフにした場合には二相変調を適用できることを示 した。一方、界磁制御スイッチ $\mathrm{S}_{0}$ をオンにした場合には インバータ出力電流が歪み、三相同一かつ三倍の周波数 の電流が流れることが分かった。以上より、提案する簡 素化した装置に二相変調を適用する場合には、界磁制御 スイッチ $\mathrm{S}_{0}$ をオフにし駆動する必要があることが今回 の解析により明らかとなった。

今後の課題として、ハイブリッド励磁形同期機の設計 が挙げられる。

\section{REFERENCES}

${ }^{1}$ T. Mizuno, K. Nagayama, T. Ashikaga and T. Kobayashi, Electrical Engineering in Japan, 117, pp. 110-123 (1996) (in Japanese).

2 T. Hirayama, H. Suzuki, Muhamed Fitri Bin Hanafi and H. Ohguchi, 2019 SAS symposium ABSTRACTS, H-9 (2019) (in Japanese).

3 The Institute of Electrical Engineers of Japan, Semiconductor power conversion circuit, pp. 124125 (1987) (in Japanese). 